\title{
The Causal Effect of Trade on Migration: Evidence from Countries of the Euro-Mediterranean Partnership
}

\author{
Nadia Campaniello*
}

March 28, 2014

\begin{abstract}
In the attempt to reduce migration pressure, since 1995, the European Union has been planning to establish a free trade area with developing countries bordering the Mediterranean Sea. The process is still ongoing. Our paper tests whether it is likely to be an effective policy. We estimate a gravitational model of bilateral migrations on bilateral exports from the Mediterranean Third Countries (South) to the European Union (North) over the period 1970-2000, using different specifications. We find, in line with most of the literature, a significantly positive correlation (called "complementarity") between exports and migrations from the South to the North. Then we go one step further, trying to solve the potential endogeneity problem using average trade tariffs and bilateral exchange rate volatility as instruments for trade. Based on the OLS as well as the 2SLS results, liberalizing trade in the area of the Euro-Mediterranean partnership does not seem to be an effective policy to mitigate the migration flows, at least in the short run.
\end{abstract}

Keywords: International trade, Migration, Causality, Gravity Model, EuroMediterranean partnership, Exchange Rate Volatility

JEL classification codes: F15, F16, F22

Acknowledgements: A special thank to Francesc Ortega, Giovanni Mastrobuoni, Tommaso Frattini, Greg Wright, Tim Hatton, Abhishek Chakravarty, Stefano Bolatto, Gianluigi Vernasca, Joshua R. Goldstein and Guy Stecklov for their useful suggestions. Finally we thank all the participants to the 2013 Alpine Population Conference, to the 25th Annual Conference of the European Association of Labour Economists and to the Essex FRESH Meeting for their useful comments.

\footnotetext{
*University of Essex, UK, ncampa@essex.ac.uk
} 


\section{Introduction}

The relationship between international trade and migration has been long debated, especially for its policy implications.

The use of trade policy to deal with the migration problem has been considered by both the European Union and the United States policy-makers. Their view is that opening their markets to exports from countries in the South reduces the pressure to migrate. In particular, Presidents Carlos Salinas and George H. W. Bush argued that the North American Free Trade Agreement (NAFTA) would have helped Mexico to export more goods and less people, while EU countries hope, more or less explicitly, that migration flows from the South Mediterranean shore to the North will decrease as a consequence of the beneficial impact of trade liberalisation on employment and living standards in the sending countries (Garson, 1998). These statements are based on the view that trade liberalization would have increased the level of exports from the Southern countries increasing labour demand and wages in the same countries, therefore decreasing migration from these countries.

Zimmermann (1995) suggests that stagnating and aging populations like those of the European Union tend to attract migrants, while young and large populations, like those of North Africa, tend to be more prone to move. In Figure 5 (in the appendix) we plot the population trends in each of the European country that we consider in our analysis. The population growth has been very low, on average 14\%, between 1970 and 2010. Since we use official data on migration and do not have information on the illegal migrants, such numbers represent lower bounds. All the Third Mediterranean Countries (TMCs) show larger increasing trends in population 6] (in the appendix). With a few exceptions, migration flows are also trending up- 
wards. 1

This evidence suggests that migrations to Europe will keep on being a major concern in the next few decades. For this reason the EU has shown an increasing interest in the Mediterranean region and has tried to create an interregional framework of cooperation that could contribute to prevent the Mediterranean to be a conflicting frontier. In 1995 the European Union signed the Barcelona Declaration that is the founding act of a partnership between the European Union and twelve countries in the Southern Mediterranean (now re-launched with the Union for the Mediterranean) to help the economic development of the Third Mediterranean Countries, especially through trade liberalization, in an attempt to reduce migratory flows from such areas. This paper is going to test whether this policy is likely to be effective in reducing migrations in the short-run. We use bilateral exports and migration flows from the 12 South Mediterranean countries (Morocco, Algeria, Tunisia, Egypt, Israel, Jordan, Palestinian Territories, Lebanon, Syria, Turkey, Cyprus and Malta) to the 15 European Union ones (Belgium, Denmark, Germany, Greece, Spain, France, Ireland, Italy, Luxembourg, Netherlands, Austria, Portugal, Finland, Sweden, United Kingdom) that signed the Euro-Mediterranean partnership over the period 1970-2000 (Figure 4 in the appendix). In our paper we refer to the EU countries as "North", while to the others as "South".

Quite surprisingly there are no studies that consider the relationship between trade

\footnotetext{
${ }^{1}$ The reasons for these exceptions (Algeria, Libya and Malta) are different. In 1973 the Algerian government, after the large migration wave to France in previous decades, and thanks to its natural resources (oil and gas), decided to prohibit out-migration, which was considered a form of postcolonialism. For the next three decades migration was just driven by French family reunification schemes (Di Bartolomeo et al., 2010). Libya has recorded more immigration than emigration flows, thanks, again, to its natural resources and the lack of internal labour supply, that attracted people from Arab countries (Di Bartolomeo et al., 2011). Malta experienced a terrific emigration from 1945 to 1979 due to over-population and unemployment, while in the following decades became a country of destination of migration flows (Plowman, 2010).
} 
and migration looking at all the countries of the Euro-Mediterranean partnership, which represents the EU's first comprehensive policy for the region and one of its most ambitious and innovative foreign policy initiatives.

Furthermore, the empirical studies on this topic, that we are going to mention later in the literature review, disregard the potential reverse causality between trade and migrations. We go further trying to identify the causal effect of trade on migration. To this aim we use an instrumental variable approach exploiting information on factors that are likely to influence the relationship between Southern exporting firms and Northern importing firms without directly influencing migration. These factors are the trade tariffs in the destination countries and the exchange rate volatility between pairs of exporting and importing countries.

As a first preliminary evidence of the relationship between trade and migration, Figure 1 shows that over the 1970 to 2000 period the correlation between the logmigration (over population) and log-export (over GDP) from the Southern Mediterranean countries to the $\mathrm{EU}$ is undoubtedly positive. But in this figure we are not controlling for several confounding factors, observable and unobservable ones, that might bias the results towards finding a positive elasticity. For example, Southern Mediterranean countries that are closer to Europe might, because of that, export more and have more migrants. This means that it is certainly important to control for the distance between countries to partial out the effect of trade on migration. All the OLS results show an elasticity between trade and migration of around $40 \%$. When using average trade tariffs and bilateral exchange rate volatility as instruments for trade the results of the instrumental variable are larger, but we cannot reject the hypothesis that they are the same. Trade does not reduce migration, at least in the short run. The paper is structured as follows: in section 2 we present 
the literature review, in section 3 the empirical strategy, while we show and discuss the results in section 4 . In section 5 we identify the causality using an instrumental variable approach to cope with the potential endogeneity problem and to measure the effect of trade on migration. Section 6 is devoted to some robustness checks. Finally section 7 presents the conclusions and the policy implications.

\section{$2 \quad$ Literature Review}

Most of the research on trade and migration focuses on investigating the relationship of complementarity or substitutability between trade and factor movements (capital and labour). This relationship has been widely studied at a theoretical level, while the empirical evidence is rather scarce.

Traditional theory suggests that both should be substitutes. Mundell (1957) used the Heckscher-Ohlin model to demonstrate that trade and factor movement are substitutes: countries can either export labour-intensive goods or have their labour migrate to produce them in the destination country. Similarly, Layard (1992) claims that the substantial migration pressure from the East and South can be reduced by exporting capital, and liberalizing trade.

Modern trade theory and extensions of traditional models show that the relationship can also be of complementarity. Several theoretical papers (Markusen, 1983, Wong, 1983) perturb some of the assumptions underlying the Heckscher-Ohlin model (e.g. different technologies or scale effects in production), and trade and migration become complements. The idea is that with migration labour can move where it is most productive and increase output and exports.

Lopez and Schiff (1998) demonstrates that complementarity is more likely the higher the migration costs, the tighter the credit constraints of migrants, and the 
lower the skills and income of potential migrants. It means that opening markets in the North is more likely to slow down migration from Eastern Europe to the EU than from Africa to the EU, or from Latin America to the U.S. Furthermore, free trade may worsen the skill composition of migration from Africa to the EU and from Latin America to the U.S.

The empirical papers on this subject are quite recent and mainly based on studies which consider trade and migration flows between a single country and the rest of the world. Bruder (2004) focuses on "North to North" trade and labour migration between Germany and some other European country. The findings indicate that there is a relationship of substitution between trade and foreign labour force. In particular they find that there isn't a significant impact of labour migration on trade, while there is a significantly negative effect of trade on labour migration.

Akkoyunlu and Siliverstovs (2009) investigate whether migration and trade are complements or substitutes using 1963-2004 data on Turkish migration to Germany. Cointegration analysis shows that migration and trade are complements for these two countries. But many other countries signed the Mediterranean agreements. We are going to use data on all of them.

Collins et al. (1997) try to use a more flexible approach to highlight for which economies of the "Atlantic community" (plus Australia) between 1870 and 1940 factor mobility and international trade have been complements or substitutes. They find that they were rarely substitutes and often complements.

Acevedo and Espenshade (1992) and Martin (1993) show that in the shortto-medium period NAFTA is likely to increase migrations from Mexico to the United States, but that narrowing the wide economic differentials between the two countries could substantially reduce the migratory flow. Martin (1993) predicts 
how NAFTA's 1994 trade liberalization influences short and long-term migration patterns between Mexico and the US. His prediction were in part confirmed by Del Rio and Thorwarth (2009), who look at more recent data for the US and Mexico. In line with Lopez and Schiff (1998)'s theoretical predictions they find no evidence of decreasing flows of illegal migrants between Mexico and the US when bilateral trade increases (with the creation of NAFTA). Bettin and Lo Turco (2010) look at the relationship between trade and migration in a North-South framework using OECD countries. They use a specific measure of imports and exports: primary and final goods and labour and capital intensive goods. They find that bilateral trade in differentiated goods is positively affected by the stock of immigrants from the South in developed countries; the effect is larger for exports than for imports. Girma and Yu (2002) find that immigration in the United Kingdom from non-Commonwealth countries has a significant and positive impact on UK exports, while there is no effect when they consider Commonwealth countries. As for UK imports, they find a relationship of complementarity with UK immigration from the non-Commonwealth countries, and a relationship of substitutability from the Commonwealth countries. Faini and Venturini (2010) use a sample of Southern European countries that included Greece, Portugal, Spain, and Turkey and estimate two different effects of GDP growth (for example due to an increase in exports) on the propensity to migrate, that depends on the level of income of the potential sending countries. In relatively poor sending countries, an increase in GDP has a positive impact on the decision to migrate even after controlling for the income differential with the receiving country, because the financial constraint of the poorest become less binding. Their results suggest that the pressure to migrate from Northern African countries and other developing countries may increase with further growth. In the second sce- 
nario, when the sending country is relatively better off (they estimate $\$ 4,300$ in 1985

prices as a threshold), an increase in income may decrease the migratory pressure. Overall most studies on "South-North" migration and trade find these to be complements. The problem of all these papers is that they look at simple correlations and not at causal effects. As mentioned by Gen et al. (2011), just a few papers try to tackle the problem of endogeneity, focussing on the effect of migration on trade, rather than on the effect of trade on migration. Furthermore the identification strategy of these papers is not very convincing, as they use the lags of migration as a instrument for migration under the assumption that past migrant flows are based on historical networks and 'well-trodden paths' rather than current economic conditions. This instrument would not be valid if current trade depends also on past migrations, violating the assumption of orthogonality between the instrument and the error term. To the best of our knowledge there are no papers that try to identify the causal effect of trade on migration. This is exactly the aim of our study.

\section{The empirical strategy}

\subsection{The gravity model}

In our paper we adopt the most popular model used to explain international migration patterns: the gravity model, first introduced by Tinbergen (1962) and Poyhonen (1963) for bilateral trade 2

The theory has been long recognized for its empirical success in explaining different types of flows in economics, such as migration, commuting, shopping trips,

\footnotetext{
${ }^{2}$ This model has been borrowed by physics, in particular by the Newton's law of universal gravitation, which states that the gravitational attraction exerted on an object by a body, decreases with the squared distance between the objects attracted and is proportional to the masses of the bodies.
} 
tourism, and trade. Furthermore the gravity model has a rather high explanatory power, which makes it an attractive specification to test the marginal influence of additional explanatory variables, such as language similarity, colonial ties, exchange rates, contiguity and trade agreements (Gen et al., 2011). The amount of migration between two countries is likely to increase in the economic size of the countries (measured by their GDP) and decreasing in the cost of transportation between them (measured by geographical distance).

We use a log-linear gravity model of migrations and the empirical specification is the following:

$$
\begin{aligned}
\ln M_{i j t}= & \beta_{0}+\beta_{1} \ln P G D P_{i t}+\beta_{2} \ln P G D P_{j t}+\beta_{3} \ln P O P_{i t}+\beta_{4} \ln P O P_{j t}+\beta_{5} \ln D_{i j}+ \\
& +\beta_{6} \ln E_{i j t}+\beta_{7} \ln E X R_{i j t}+\beta_{8} C_{i}+\beta_{9} Y_{t}+\alpha_{i}+\alpha_{j}+\gamma_{i} * Y_{t}+\gamma_{j} * Y_{t}+\varepsilon_{i j t}
\end{aligned}
$$

where the subscript $i$ and $j$ represent, respectively, each of the 12 Southern and 15 Northern countries that signed the Euro-Mediterranean partnership, $t$ are the years 1970, 1980, 1990 and 2000, $M$ measures migrations from the Southern Mediterranean Countries, $P G D P$ is the Purchasing Power Parity (PPP) converted GDP, $P O P$ is the population, $D$ is the bilateral geographic distance, $E$ is the bilateral export flow from Southern Mediterranean countries to 15-EU, EXR is the bilateral exchange rate (importing country currency divided by exporting country currency, normalized to be 1 in 1970), $C$ is a dummy for ex-colony, $Y$ is the year, $\alpha$ are country fixed effects (FEs) of country of origin and/or destination that capture all the unobserved, time-constant factors that affect migrations, $\gamma_{i}{ }^{*} Y_{t}$ and $\gamma_{j}{ }^{*} Y_{t}$ are country (respectively of origin and of destination) specific trends. Finally, $\varepsilon$ are the idiosyncratic errors. 
We are interested in the coefficient of the trade exports variable $\mathrm{E}$, that is $\beta_{6}$. If it is statistically significant and positive, it means that migration and export are complements; while if it is statistically significant and negative, it means that they are substitutes. Table 1 shows the descriptive statistics, with two different samples: the full sample used in the OLS and the sample used in the IV strategy. The data sources are reported in the appendix. Given that adding country and time fixed effects may be quite data demanding, in Table 2 we show how much variability, both unconditional and conditional (adding all the regressors that we will use in the empirical estimation) is captured by combinations of such effects ( 1 minus the R-squared measures how much variation is left in the data). Each entry in the table represents a different linear regression. The first row, for example, shows that a linear time trend captures $7 \%$ of the variation of our dependant variable, $\log$ Migration. This number is only slightly lower than what is captured using year effects (column 2). The same is true for log Export in the second row of the table, especially when one conditions on all the other regressors. The only variable that preserves more variation conditional on a linear trend than on year fixed effects is one of our instruments, namely, the log Bilateral exchange rate volatility. In this case, year fixed effects capture ten times more variability than the linear trend in the unconditional setting and one time more variability in the conditional one (see columns 1 and 2 of table 2). Thus, in order to preserve the strenght of our instrument we are going to use linear trends when using the instruments and, for coherence, also in the OLS specifications 3 Adding country fixed effects and their interaction with a linear time trend captures a large degree of variation for all the variables. Country FEs capture the countries unobserved heterogeneity. In other words they

\footnotetext{
${ }^{3}$ In the OLS all the results are preserved when using year fixed effects.
} 
reflect all factors of the sending or receiving country that influence the decision to migrate but do not change over time, such as institutions, culture, and attitudes toward immigration that vary considerably across countries, but very slowly within countries over time (Ortega and Peri, 2012). Together with country specific trends (in particular for the country of origin) they also capture the potential "multilateral resistance" (see Anderson and Van Wincoop (2003) with respect to bilateral trade flows and Ortega and Peri (2012, 2013) with respect to bilateral migration flows) or, in other words, the influence that possible destinations exert on the decision to migrate to a given destination. Bertoli and Fernández-Huertas Moraga (2013) use the Common Correlated Effects estimator proposed by Pesaran (2006) to tackle the issue of multilateral resistance to migration, but argue that, to be applied, it requires a long panel and that, in case of a short panel, the methodology proposed by Ortega and Peri (2012, 2013) might be used instead. Since we have a short panel we are going to use their approach. Given the variability of our data, we can control for "multilateral resistance" when using OLS, while when using the 2SLS strategy, the country fixed effects weaken the IV too much. Yet, later we will show that there is little evidence of multilateral resistance and that the OLS and IV estimates are quite close to each other (indeed we cannot reject the two to be the same). Finally, when using the interaction of the country of origin and country of destination fixed effects (see column 7 of table 2) too little variability is left to be explained. To solve the problem of heteroskedasticity due to intragroup correlations we cluster the standard errors at the country of destination and origin level in all our estimates. 


\section{Results}

Table 3 shows our estimates of the gravitational equation using alternative specifications with and without fixed effects. Column 1 shows that controlling for distance, origin and destination GDP, origin and destination population, a linear function of year, the bilateral exchange rate (normalized to be 1 in 1970), and to be an ex-colony of the destination country reduces the elasticity of migration with respect to trade from almost 80 percent we had in Figure 1 to 44 percent. In column 2 we use time fixed effects instead of the linear trend and, in line with what we found in table 2. the results are similar. Adding country of origin FE (column 3) or country of destination FE (column 4) does not substantially alter the elasticity. Adding both FEs (column 5) reduces the coefficient by a little bit. Including country specific trends (column 6) the coefficient on the exports is very close to that of column 1. Trade and migration appear to be complements (they move in same direction), but the positive correlation may be driven by reverse causality or by an omitted variable and we cannot infer any causal relationship.

As for the other regressors, the most important determinants of migration to the EU countries are distance and the population of the country of origin (see Karemera et al., 2000). The coefficient on distance is significant with the expected negative sign, because it affects the cost of migration. The estimated elasticity is close to -1. Population has always a positive sign for the country of origin and a negative one for those of destination. Such negative sign is capturing that what matters for migration decisions is GDP per capita and not total GDP. The coefficients on the two GDPs are significant in more than half of the specifications: with a negative sign for the country of origin and a positive sign for the country of destination. This is again in the direction that we expected, because people tend to 
migrate from poorer (South Mediterranean shore) to richer countries (EU), where income opportunities are higher (see Mavda, 2010). The bilateral exchange rates (normalized to 1970) are negative in all the specifications, but significant in 3 of them. The reason might be that people decide to migrate to countries where the exchange rate with their country of origin is low, because the remittance receipts

are larger and, in case of temporary migrations, they can accumulate savings (Yang, 2008). Time is significant (and negative) just for the baseline gravity equation. Past colonial relationship positively affects the migration flows in all the specifications we use. South-North migration is positively correlated to South-North exports.

\section{Causality}

Fixed effect specifications may not be able to capture time varying unobserved heterogeneity, and thus be unable to identify the causal mechanism between trade and migration. As we mentioned before the correlation between the two variables might due to an omitted variable we do not control for or to reverse causality: migrations may increase trade. To address the endogeneity problem we adopt a Two Stage Least Square (2SLS) approach, that uses two different instruments for trade flows, which are plausibly exogenous with respect to migration: average trade tariffs and bilateral exchange rate volatility.

Trade tariffs are all levies collected on goods that are entering the country or services delivered by nonresidents to residents. They include levies imposed for revenue or protection purposes and determined on a specific or ad valorem basis as long as they are restricted to imported goods or services. In other words these taxes increase the 
cost of imported goods, giving an advantage to the domestic producers. We first collected data on tax revenues on customs and other import duties over GDP and then data on total imports at country level for all the 15-EU countries. In this way we calculate the percentage of taxation applied to imports for each country (from now on we will refer to it as to tariff or trade tariff). We are going to show that tariffs predict trade flows, but are they also a valid instrument, meaning that migration does not depend on tariff other than trough trade? The way tariffs are measured in this paper make them not only depend on bilateral trade agreements and international agreements but also on the cost of custom operations. The identification assumption of this paper is that such an aggregate measure of tariffs does not depend on migratory flows. In other words, we assume that governments set overall trade tariffs to influence trade and not migration flows. Suppose EU countries set bilateral tariffs to influence trade but also migration. In such case one would like to use the part of tariffs that is set to influence overall trade and not migration from a specific country as an instrument. A potential measure for such part would be the tariffs versus all the non-Third Mediterranean countries. Unfortunately data bilateral tariffs are not available back in time, but since we are using an imports-weighted aggregate measure of tariffs, such aggregate is going to be very similar to the measure that excludes these countries as long as imports from Third Mediterranean Countries are small with respect to all the other imports. Indeed, their exports to EU countries represent between 0.04 percent (Portugal) and 0.23 percent (Italy) of total imports to these countries. Table 4 shows the trade tariffs of the EU countries in the years 1970, 1980, 1990 and 1997. We use 1997 because it's the first year going back from the 2000 with a complete and coherent measurement for the countries we look at. Note that there is a decreasing trend for tariffs 
from 1970 to 1997 for all the EU countries. The most dramatic variation is from 1970 to 1980 (on average -72\%). This is not surprising because during the oil and financial crises of the 1970s protectionism was widespread in world trade. In Figure 2 we plot tariffs of European countries (the instrument) against their imports from Third Mediterranean partners (the instrumented variable) after conditioning on all the regressors used later in the main specification (Column 1 of Table 3). There is clearly a negative correlation between the two variables. The coefficient in a simple bivariate regression is equal to 0.48 .

As a second instrumental variable we use the bilateral exchange rate volatility. There is consistent evidence in the literature that exchange rate volatility negatively affects bilateral trade (Byrne et al., 2008, Chowdhury, 1993, Dell'Ariccia, 1998, Pozo, 1992). The argument is that by increasing uncertainty and risk, if hedging is impossible or costly, risk-averse agents are discouraged to engage in trade, especially since trade relations between exporting and importing firms are bound to persist over time. Expectations of future volatility are based on past trends and for this reason we consider a period of 10 years. We normalize the annual bilateral exchange rates over a 10-year period to the exchange rate of the first year of each decennial period $(1970,1980,1990,2000)$ and then calculate the variance. In figure 3 we plot exports against exchange rate volatility after conditioning on all the other regressors used later in the main specification (Column 1 of Table 3). There is a clear negative correlation between the two variables. While there is no empirical evidence that tariffs are set in order to control migration and that the second moment of exchange rates determines migratory flows (for example none of the papers that we are aware of control for the second moment of exchange rate when explaining migratory flows), having two instruments allows us to perform an overidentification 
test. Even if nobody has ever made this point before, one might argue that immigrants might choose the country of destination taking the variability of the exchange rate into consideration in order to smooth potential future remittances and that the average trade tariffs are set taking bilateral migratory flows into account. If this was the case, the fact that we cannot reject the overidentification test means that the biases introduced by the two instruments would have to be the same, which is arguably unlikely. The results from the first stage are shown in Table 5. Table 6 shows the results of the IV (2SLS) estimation using both the bilateral exchange rate volatility and average trade tariffs as instruments. The first stage F-statistic is equal to 19.251 , which is above the rule of thumb value of 10 indicated by the literature on weak instruments (Bound et al., 1995, Stock and Yogo, 2002). Then we use the $J$-statistic to test the exogeneity and we find a p-value equal to 0.674.

Finally, we use the Hausman $t$ statistic to compare OLS and 2SLS estimates of the coefficient on exports finding no evidence of endogeneity (the p-value is equal to 0.43). The results that we find with the 2SLS are in line with those of the OLS. In particular the coefficient of interest, that on exports, is significant and positive. Note that in the IV there is no variation left after controlling for the FEs (see table 2), but adding those FEs change the OLS estimates very little, suggesting that the bias is small and is likely to be small for the IV as well. Moreover, as already pointed out, the estimate based on the IV specification is not statistically different from the model that assumes that trade is exogenous to migration. To conclude, exports, at least in the short run, do not seem to mitigate the migration pressure, but to encourage it. 


\section{Robustness checks}

In this section we perform different robustness checks to be sure that our results are not biased by the particular specification we used. First of all we run the regressions using a Poisson estimator, as suggested by Silva and Tenreyro (2006): under heteroskedasticity, the parameters of log-linearized models estimated by OLS lead to biased estimates of the true elasticities. We find a positive and significant semi-elasticity of 1.297 on the coefficient export. As a second robustness check, we introduce as a regressor in the OLS the sum of all exports from a given Third Mediterranean Country $i$ to all European Union countries excluding country $j$, allowing for an indirect effect on migrations towards the European country $j$. We find a higher coefficient compared to that of the baseline specification of the OLS, equal to 0.526 on the variable export.

One could argue that since we are controlling for GDP of the country of origin, the elasticity is bound to be positive. Migration flows might decrease when countries export more and become richer, but controlling for country of origin GDP we are shutting off such a channel. This is the reason why in the third robustness we subtract exports from GDP. In this way an increase in export determines a one to one increase in GDP. Doing so barely changes the results. An alternative way to completely get rid of GDP is not to control for country of origin GDP. The coefficient on the variable export is the same as in the main specification.

Another objection could be related to the inclusion of Israel and Malta among the Southern countries. Indeed their economic conditions are very similar to those of the EU countries. For this reason we run the regressions without Malta and Israel and we find very similar results. As shown in table 7 in all of these robustness checks we find a positive and significant relationship between trade and migration. All these 
results are in line with those of the main analysis.

\section{Conclusions}

In 1995 European Union policymakers decided to establish a free trade area in the region of the Euro-Mediterranean partnership hoping that such policy would increase trade (in particular exports from the TMCs) and that, in turn, trade would lead to a reduction in migration. The process is still ongoing. Policy makers assumed that trade has a negative effect on migrations. In our paper we find, looking at the period 1970-2000, that the effect is the opposite: exports increase migration. Such a conclusion is reached not just looking at simple correlations between trade and migration, but trying to solve the potential endogeneity problem using an instrumental variable approach. In particular we adopt a 2SLS approach that use average trade tariffs and bilateral exchange rate volatility as instruments for trade flows. We find that increasing trade is likely to increase the number of migrants from Southern Mediterranean to the European Union. These results might be driven by the creation of links between the countries involved in trade: migrants need these links to enter the receiving country. For example Italy sets immigration quotas that can only be filled by migrants with a job offer in Italy. We just conclude saying that EU policymakers should not consider free trade as a valid policy to decrease migrations from the Third Mediterranean countries to Europe, at least in the short run. Due to data limitations it is impossible to analyze whether such patterns can be reversed in the long-run, when Southern countries will have converged to the economic development of Northern ones (see Faini and Venturini, 2010). 


\section{References}

D. Acevedo and T.J. Espenshade. Implications of a North American Free Trade Agreement for Mexican migration into the United States. The Population and Development Review, pages 729-744, 1992.

S. Akkoyunlu and B. Siliverstovs. Migration and Trade: Complements or Substitutes? Evidence from Turkish Migration to Germany. Emerging Markets Finance and Trade, 45(5):47-61, 2009.

James E Anderson and Eric Van Wincoop. Gravity with gravitas: A solution to the border puzzle. The American Economic Review, 93(1):170-192, 2003.

Simone Bertoli and Jesús Fernández-Huertas Moraga. Multilateral resistance to migration. Journal of Development Economics, 102:79-100, 2013.

G. Bettin and A. Lo Turco. A Cross Country View on South-North Migration and Trade. Dissecting the Channels. Working Paper Università della Calabria, 10(15): 35, 2010.

J. Bound, D.A. Jaeger, and R.M. Baker. Problems with instrumental variables estimation when the correlation between the instruments and the endogeneous explanatory variable is weak. Journal of the American Statistical Association, pages 443-450, 1995.

J. Bruder. Are trade and migration substitutes or complements? The case of Germany, 1970-1998. European Trade Study Group, pages 9-11, 2004.

Joseph P Byrne, Julia Darby, and Ronald MacDonald. Us trade and exchange rate 
volatility: A real sectoral bilateral analysis. Journal of macroeconomics, 30(1): 238-259, 2008.

Abdur Chowdhury. Does exchange rate variability depress trade flows? evidence from error correction models. Review of Economics and Statistics, 1993.

W.J. Collins, K.H. O'Rourke, and J. Williamson. Were trade and factor mobility substitutes in history? Technical report, National Bureau of Economic Research, 1997.

A.M. Del Rio and S. Thorwarth. Tomatoes or tomato pickers? Free trade and migration between Mexico and the United States. Journal of Applied Economics, 12(1):109-134, 2009.

Giovanni Dell'Ariccia. Exchange Rate Fluctuations and Trade Flows-Evidence from the European Union. International Monetary Fund, 1998.

A. Di Bartolomeo, T. Jaulin, and D. Perrin. Algeria. The Demographic-Economic Framework of Migration. The Legal Framework of Migration. The Socio-Political Framework of Migration. Technical report, Robert Schuman Centre for Advanced Studies, December 2010.

A. Di Bartolomeo, T. Jaulin, and D. Perrin. Libya. The Demographic-Economic Framework of Migration. The Legal Framework of Migration. The Socio-Political Framework of Migration. Technical report, Robert Schuman Centre for Advanced Studies, June 2011.

R. Faini and A. Venturini. Development and migration: Lessons from southern europe. In Frontiers of Economics and Globalization, volume 8, chapter 5. Emerald Group Publishing Limited, 2010. 
R. C. Feenstra, R. E. Lipsey, H. Deng, A. C. Ma, and H. Mo. World trade flows: 1962-2000. NBER Working Paper, 2005.

J.P. Garson. Opening Mediterranean Trade and Migration. OECD OBSERVER, pages 21-24, 1998.

M. Gen, M. Gheasi, P. Nijkamp, and J. Poot. The impact of immigration on international trade: a meta-analysis. Norface Discussion Paper Series, 2011.

S. Girma and Z. Yu. The link between immigration and trade: Evidence from the United Kingdom. Review of World Economics, 138(1):115-130, 2002.

D. Karemera, V.I. Oguledo, and B. Davis. A gravity model analysis of international migration to North America. Applied Economics, 32(13):1745-1755, 2000.

P.R.G. Layard. East-West migration: the alternatives. The MIT Press, 1992.

Ramon Lopez and Maurice Schiff. Migration and the skill composition of the labor force: The impact of trade liberalization in ldcs. Canadian Journal of Economics, 31:318-336, May 1998.

J.R. Markusen. Factor movements and commodity trade as complements. Journal of International Economics, 14(3-4):341-356, 1983.

P.L. Martin. Trade and migration: Nafta and agriculture. Technical report, Policy Analysis in International Economics, Washington D.C., 1993.

A.M. Mayda. International migration: A panel data analysis of the determinants of bilateral flows. Journal of Population Economics, 23(4):1249-1274, 2010.

R.A. Mundell. International trade and factor mobility. The American Economic Review, 47(3):321-335, 1957. 
Francesc Ortega and Giovanni Peri. The effect of trade and migration on income. Technical report, National Bureau of Economic Research, 2012.

Francesc Ortega and Giovanni Peri. The effect of income and immigration policies on international migration. Migration Studies, 1(1):47-74, 2013.

M Hashem Pesaran. Estimation and inference in large heterogeneous panels with a multifactor error structure. Econometrica, 74(4):967-1012, 2006.

D. H. Plowman. A Fragment of the Maltese Exodus: Child Migration to Australia 1953-1965. Journal of Maltese History, 2(1), 2010.

P. Poyhonen. A tentative model for the volume of trade between countries. Weltwirtschaftliches Archiv., 90(1):93-99, 1963.

Susan Pozo. Conditional exchange-rate volatility and the volume of international trade: evidence from the early 1900s. The Review of Economics and Statistics, $74(2): 325-29,1992$.

JMC Santos Silva and Silvana Tenreyro. The log of gravity. The Review of Economics and Statistics, 88(4):641-658, 2006.

J.H. Stock and M. Yogo. Testing for weak instruments in linear IV regression. Technical report, National Bureau of Economic Research, 2002.

J. Tinbergen. Shaping the world economy. suggestions for an international economic policy. Technical report, Twentieth Century Fund, New York, 1962.

K.Y. Wong. On choosing among trade in goods and international capital and labor mobility: A theoretical analysis. Journal of International Economics, 14:223-250, 1983. 
Dean Yang. International migration, remittances and household investment: Evidence from philippine migrants' exchange rate shocks. The Economic Journal, 118(528):591-630, 2008.

K.F. Zimmermann. Tackling the european migration problem. The Journal of Economic Perspectives, 9(2):45-62, 1995. 


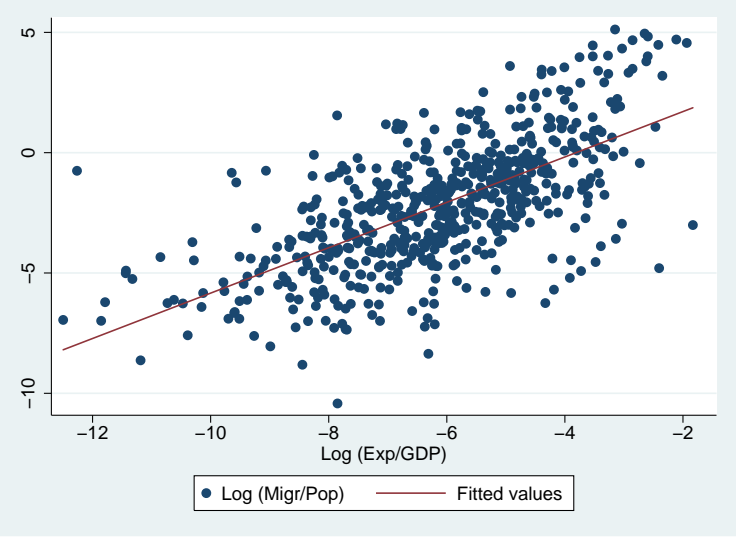

Figure 1: Correlation between migration (over population) and export (over GDP) from the Southern Mediterranean Countries to the EU in 1970-2000.

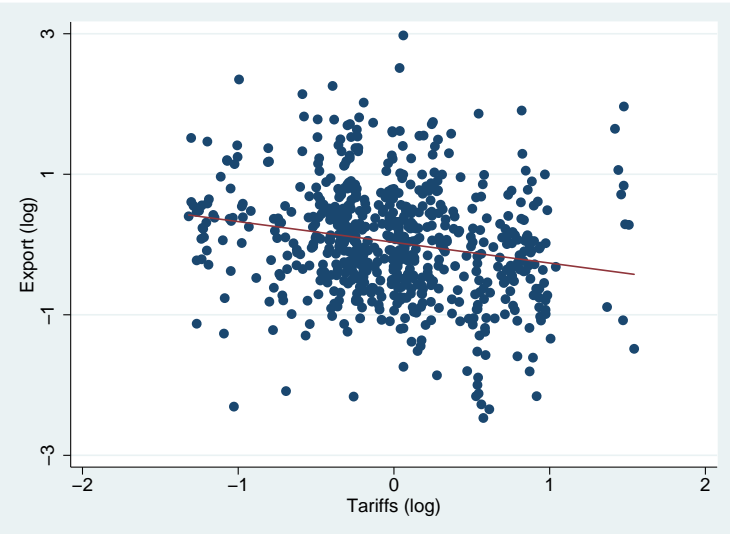

Figure 2: EU countries average trade tariffs and the exports (over GDP) arriving from the Third Mediterranean countries in the period 1970-2000 (residuals).

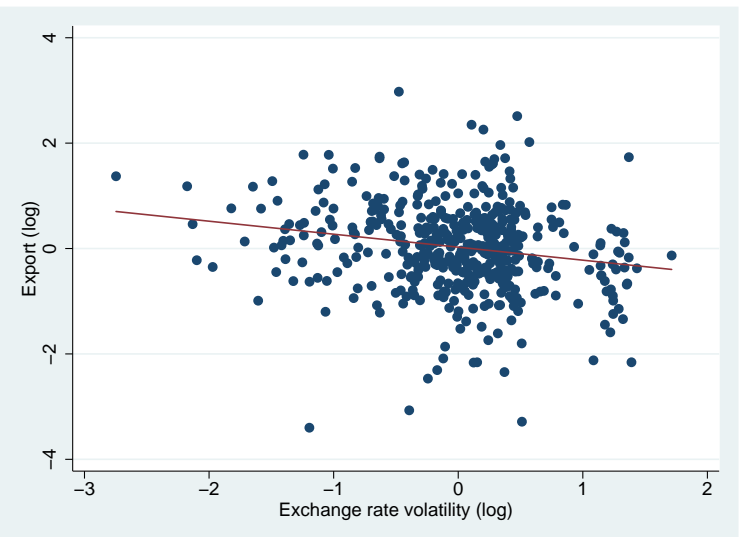

Figure 3: Bilateral exchange rate volatility and exports from the Third Mediterranean countries to EU countries (residuals) 
Table 1: Summary statistics

\begin{tabular}{lcccccc}
\hline & Mean & Std. Dev. & & Mean & Std. Dev. \\
\cline { 1 - 2 } \cline { 5 - 6 } & \multicolumn{2}{c}{ Full sample } & & \multicolumn{2}{c}{ IV sample } \\
\cline { 2 - 3 } \cline { 6 - 7 } Migration & 27501.59 & 140609.5 & & 29570.08 & 142912.4 \\
Exports & 214.67 & 475.45 & & 275.729 & 531.819 \\
Distance & 2497.26 & 875.05 & & 2493.36 & 877.09 \\
GDP_country of origin (CoO) & 52555.22 & 87252.44 & & 66717.62 & 96010.6 \\
GDP_country of destination (CoD) & 322217.5 & 418843.7 & & 397961 & 453535.2 \\
Pop_country of origin & 16349.98 & 18605.23 & & 17961.94 & 19930.52 \\
Pop_country of destination & 22972.01 & 23882.38 & & 22754.76 & 23468.92 \\
Year & 1985.19 & 11.17 & & 1990.09 & 8.155 \\
Colony & 0.55 & 0.50 & & 0.53 & 0.5 \\
Bilateral Exchange Rates (normalized to 1970$)$ & 0.80 & 0.87 & & 0.73 & 0.99 \\
Sum of exports from each of the CoO & 3478.66 & 4723.76 & & 4494.23 & 5028.01 \\
Trade Tariffs & - & - & & 0.08 & 0.09 \\
Bilateral Exchange Rate Volatility & - & & & 0.22 & 0.13 \\
Observations & 590 & 590 & & 446 & 446 \\
\hline
\end{tabular}

Notes: Data on Migrations are expressed in thousands of migrants while data on Exports, GDP and Population are expressed in US million dollars. Distance is in kilometers. Bilateral exchange rate volatility is computed over a 10-year period. We two different samples: the full sample used in the OLS and the sample used in the IV strategy. 
Table 2: Data variability

\begin{tabular}{|c|c|c|c|c|c|c|c|c|}
\hline & \multicolumn{7}{|c|}{ R-squared } & \\
\hline & \multicolumn{8}{|c|}{ Unconditional } \\
\hline & (1) & $(2)$ & (3) & $(4)$ & $(5)$ & (6) & (7) & (8) \\
\hline Log Migration & 0.066 & 0.067 & 0.319 & 0.402 & 0.687 & 0.716 & 0.874 & 0.901 \\
\hline Log Export & 0.241 & 0.300 & 0.329 & 0.699 & 0.793 & 0.822 & 0.855 & 0.885 \\
\hline Log Average Trade Tariffs & 0.436 & 0.503 & 0.436 & 0.822 & 0.822 & 0.884 & 0.822 & 0.884 \\
\hline \multirow{3}{*}{ Log Bilateral Exchange rate volatility } & 0.019 & 0.212 & 0.281 & 0.088 & 0.357 & 0.552 & 0.435 & 0.626 \\
\hline & \multicolumn{8}{|c|}{ Conditional } \\
\hline & (1) & $(2)$ & $(3)$ & $(4)$ & $(5)$ & $(6)$ & $(7)$ & $(8)$ \\
\hline Log Migration & 0.583 & 0.593 & 0.684 & 0.636 & 0.728 & 0.758 & 0.880 & 0.907 \\
\hline Log Export & 0.835 & 0.839 & 0.854 & 0.859 & 0.881 & 0.909 & 0.928 & 0.956 \\
\hline Log Average Trade Tariffs & 0.728 & 0.748 & 0.732 & 0.852 & 0.858 & 0.930 & 0.860 & 0.930 \\
\hline Log Bilateral Exchange rate volatility & 0.166 & 0.374 & 0.378 & 0.262 & 0.467 & 0.731 & 0.543 & 0.805 \\
\hline Year & Yes & No & Yes & Yes & Yes & Yes & Yes & Yes \\
\hline Year Fixed Effects (FE) & No & Yes & No & No & No & No & No & No \\
\hline Country of or. (CoO) FE & No & No & Yes & No & Yes & Yes & Yes & Yes \\
\hline Country of de. (CoD) FE & No & No & No & Yes & Yes & Yes & Yes & Yes \\
\hline CoO*year FE \& CoD*year FE & No & No & No & No & No & Yes & No & Yes \\
\hline $\mathrm{CoO}^{*} \mathrm{CoD} \mathrm{FE}$ & No & No & No & No & No & No & Yes & Yes \\
\hline $\mathrm{CoO} \& \mathrm{CoD}$ Time trends & No & No & No & No & No & No & No & Yes \\
\hline
\end{tabular}

Notes: The table shows how much variability, both unconditional and conditional (adding all the regressors that we will use in the empirical estimation) is captured by the fixed effects or, substracting the R-squared to 1 , how much variation is left to be explained in the data. In Column 1 we use the linear trend, while in Column 2 we use year fixed effects. In all the other columns we use linear time trends and we add different fixed effects. In Column 3 we include origin fixed effects, while in Column 4 we include country of destination fixed effects. In Column 5 we include both origin and destination fixed effect. In Column 6 we use both origin-year and destination-year fixed effects. In Column 7 we use origin-destination fixed effect. Finally, Column 8 includes origin-destination, origin-year and destination-year fixed effects. 
Table 3: Estimates of a "South-North" gravity model of migrations on exports flows

\begin{tabular}{|c|c|c|c|c|c|c|}
\hline & \multicolumn{6}{|c|}{ Dependent variable: Log Migrations } \\
\hline \multirow{3}{*}{ Log Exports } & $(1)$ & $(2)$ & $(3)$ & $(4)$ & $(5)$ & $(6)$ \\
\hline & $0.446^{* * *}$ & $0.444^{* * *}$ & $0.403^{* * *}$ & $0.417^{* * *}$ & $0.357^{* * *}$ & $0.442^{* * *}$ \\
\hline & $(0.135)$ & $(0.139)$ & $(0.119)$ & $(0.139)$ & $(0.129)$ & $(0.153)$ \\
\hline \multirow[t]{2}{*}{ Log Distance } & $-1.526^{* * *}$ & $-1.518^{* * *}$ & $-1.293^{* * *}$ & $-1.567^{* * *}$ & $-1.240 * * *$ & $-1.215^{* * *}$ \\
\hline & $(0.304)$ & $(0.304)$ & $(0.335)$ & $(0.332)$ & $(0.424)$ & $(0.414)$ \\
\hline \multirow[t]{2}{*}{ Log Bilateral Exchange Rates } & $-0.154^{* * *}$ & $-0.131^{* * *}$ & -0.0334 & $-0.126^{* * *}$ & -0.0323 & -0.104 \\
\hline & $(0.0373)$ & $(0.0407)$ & $(0.0403)$ & $(0.0369)$ & $(0.0398)$ & $(0.104)$ \\
\hline \multirow[t]{2}{*}{ Log GDP_country of origin } & $-0.388^{*}$ & -0.216 & $-1.279 * * *$ & -0.174 & $-0.778^{* *}$ & -0.810 \\
\hline & $(0.204)$ & $(0.217)$ & $(0.272)$ & $(0.227)$ & $(0.341)$ & $(0.585)$ \\
\hline \multirow[t]{2}{*}{ Log GDP_country of destination } & $1.369^{* * *}$ & $1.750^{* * *}$ & $1.790 * * *$ & -0.0520 & 0.661 & 0.838 \\
\hline & $(0.468)$ & $(0.497)$ & $(0.424)$ & $(0.554)$ & $(0.572)$ & $(0.955)$ \\
\hline \multirow[t]{2}{*}{ Log Pop_country of origin } & $0.869 * * *$ & $0.759^{* * *}$ & $2.144^{* * *}$ & $0.745^{* * *}$ & $2.011^{* * *}$ & 3.201 \\
\hline & $(0.162)$ & $(0.169)$ & $(0.728)$ & $(0.165)$ & $(0.767)$ & $(2.740)$ \\
\hline \multirow[t]{2}{*}{ Log Pop_country of destination } & $-0.688^{*}$ & $-1.045^{* * *}$ & $-1.086^{* * *}$ & -1.521 & -2.486 & $-6.675^{*}$ \\
\hline & $(0.359)$ & $(0.387)$ & $(0.336)$ & $(2.370)$ & $(2.265)$ & $(3.683)$ \\
\hline \multirow[t]{2}{*}{ Year } & $-0.0827 * * *$ & & -0.0454 & 0.0139 & 0.00936 & -0.116 \\
\hline & $(0.0304)$ & & $(0.0303)$ & $(0.0304)$ & $(0.0316)$ & $(0.0724)$ \\
\hline \multirow[t]{2}{*}{ Colony } & $0.410^{*}$ & $0.468^{*}$ & $3.510^{* * *}$ & $0.475^{* *}$ & $3.469^{* * *}$ & $3.415^{* * *}$ \\
\hline & $(0.240)$ & $(0.241)$ & $(0.808)$ & $(0.234)$ & $(0.647)$ & $(0.649)$ \\
\hline \multirow[t]{2}{*}{ Constant } & $167.0^{* * *}$ & 2.849 & 85.95 & -0.891 & 0.322 & $272.5^{* *}$ \\
\hline & $(57.96)$ & $(3.767)$ & $(55.48)$ & $(62.96)$ & $(61.65)$ & $(114.3)$ \\
\hline Year & Yes & No & Yes & Yes & Yes & Yes \\
\hline Year Fixed Effects (FE) & No & Yes & No & No & No & No \\
\hline Country of origin (CoO) FE & No & No & Yes & No & Yes & Yes \\
\hline Country of destination (CoD) FE & No & No & No & Yes & Yes & Yes \\
\hline $\mathrm{CoO}$ and $\mathrm{CoD} F E$ & No & No & No & No & Yes & Yes \\
\hline $\mathrm{CoO}^{*}$ year FE \& CoD*year FE & No & No & No & No & No & Yes \\
\hline Observations & 590 & 590 & 590 & 590 & 590 & 590 \\
\hline R-squared & 0.605 & 0.611 & 0.687 & 0.650 & 0.727 & 0.760 \\
\hline
\end{tabular}

Notes: We regress the bilateral migrations from the 12 Mediterranean Partner Countries to the European Union Countries at 15 (South-North migration model) on their exports and on other control variables using OLS estimation. We use six different specifications. Standards errors are clustered at country of origin and country of destination. Robust standard errors are in parenthesis: *** Significant at 10\%, ** Significant at 5\%, * Significant at $1 \%$. 
Table 4: Trade tariffs

\begin{tabular}{lcccc}
\hline EU Country & 1970 & 1980 & 1990 & $1997(=2000)$ \\
\hline Austria & 0.595 & 0.078 & 0.079 & 0.033 \\
Belgium & 0.178 & 0.052 & 0.041 & 0.037 \\
Denmark & 0.134 & 0.037 & 0.034 & 0.034 \\
Finland & 0.293 & 0.100 & 0.082 & 0.029 \\
France & 0.179 & 0.045 & 0.037 & 0.034 \\
Germany & 0.254 & 0.083 & 0.064 & 0.041 \\
Greece & 0.967 & 0.508 & 0.082 & 0.052 \\
Ireland & 0.136 & 0.047 & 0.045 & 0.037 \\
Italy & 0.400 & 0.034 & 0.048 & 0.034 \\
Luxembourg & 0.047 & 0.008 & 0.009 & 0.014 \\
Netherlands & 0.255 & 0.065 & 0.068 & 0.068 \\
Portugal & 1.388 & 0.306 & 0.191 & 0.038 \\
United Kingdom & 0.233 & 0.106 & 0.073 & 0.066 \\
Spain & 0.805 & 0.231 & 0.211 & 0.045 \\
Sweden & 0.362 & 0.060 & 0.091 & 0.036 \\
\hline
\end{tabular}

Notes: We use 1997 because it is the first year going back from the 2000 with a complete and coherent measurement 
Table 5: IV: Results of the first stage.

\begin{tabular}{lc}
\hline & Dependent variable: Log Exports \\
\hline Log Bilateral Exchange Rate Volatility & $-0.309^{* * *}$ \\
Log Trade Tariffs & $(0.0619)$ \\
& $-0.294^{* * *}$ \\
Log Distance & $(0.0768)$ \\
& $-0.655^{* * *}$ \\
Log Bilateral Exchange Rates & $(0.132)$ \\
& $-0.0970^{* * *}$ \\
Log GDP_country of origin & $(0.0237)$ \\
& $0.729^{* * *}$ \\
Log GDP_country of destination & $(0.106)$ \\
Log Pop_country of origin & $1.067^{* * *}$ \\
& $(0.228)$ \\
Log Pop_country of destination & $-0.188^{* *}$ \\
Year & $(0.0840)$ \\
Colony & 0.0105 \\
Constant & $(0.225)$ \\
Observations & $-0.0830^{* * *}$ \\
R-squared & $(0.0116)$ \\
\hline
\end{tabular}

Notes: First stage results using the instrumented variable Exports as dependent variable and the instruments Average Trade Tariffs and Bilateral Exchange Rate Volatility as independent variables. Standards errors are clustered at country of origin and country of destination. Robust standard errors are in parenthesis: $* * *$ Significant at $10 \%,{ }^{* *}$ Significant at 5\%, ${ }^{*}$ Significant at $1 \%$. 
Table 6: Estimates of the IV (2SLS) regression

\begin{tabular}{|c|c|c|}
\hline & \multicolumn{2}{|c|}{ Dependent variable: Log Migrations } \\
\hline & OLS & IV \\
\hline \multirow[t]{2}{*}{ Log Exports } & $0.446^{* * *}$ & $0.766^{* *}$ \\
\hline & $(0.135)$ & $(0.318)$ \\
\hline \multirow[t]{2}{*}{ Log Distance } & $-1.526^{* * *}$ & $-1.218^{* * *}$ \\
\hline & $(0.304)$ & $(0.366)$ \\
\hline \multirow[t]{2}{*}{ Log Bilateral Exchange Rates } & $-0.154^{* * *}$ & $-0.118^{* *}$ \\
\hline & $(0.0373)$ & $(0.0504)$ \\
\hline \multirow[t]{2}{*}{ Log GDP_country of origin } & $-0.388^{*}$ & -0.540 \\
\hline & $(0.204)$ & $(0.417)$ \\
\hline \multirow[t]{2}{*}{ Log GDP_country of destination } & $1.369^{* * *}$ & $1.422^{* * *}$ \\
\hline & $(0.468)$ & $(0.537)$ \\
\hline \multirow[t]{2}{*}{ Log Pop_country of origin } & $0.869^{* * *}$ & $0.880^{* * *}$ \\
\hline & $(0.162)$ & $(0.254)$ \\
\hline \multirow[t]{2}{*}{ Log Pop_destination } & $-0.688^{*}$ & $-1.072^{* * *}$ \\
\hline & $(0.359)$ & $(0.356)$ \\
\hline \multirow[t]{2}{*}{ Year } & $-0.0827^{* * *}$ & $-0.0690^{*}$ \\
\hline & $(0.0304)$ & $(0.0362)$ \\
\hline \multirow[t]{2}{*}{ Colony } & $0.410^{*}$ & $0.604^{* *}$ \\
\hline & $(0.240)$ & $(0.277)$ \\
\hline \multirow[t]{2}{*}{ Constant } & $167.0^{* * *}$ & $140.2^{* *}$ \\
\hline & $(57.96)$ & $(68.63)$ \\
\hline \multicolumn{2}{|l|}{ First stage F-statistic } & 19.251 \\
\hline & 0.674 \\
\hline \multicolumn{2}{|l|}{$\begin{array}{l}\text { Overidentification p-value } \\
\text { Hausman p-value }\end{array}$} & \\
\hline Observations & 590 & 446 \\
\hline R-squared & 0.605 & 0.599 \\
\hline
\end{tabular}

Notes: The Two Stage Least Square (2SLS) approach uses Average trade tariffs and Bilateral exchange rate volatility as instruments for trade flows. 
Table 7: Robustness checks

\begin{tabular}{|c|c|c|c|c|c|}
\hline & \multicolumn{5}{|c|}{ Dependent variable: Log Migrations } \\
\hline & \multirow{2}{*}{$\frac{\text { Poisson }}{(1)}$} & \multicolumn{4}{|c|}{ OLS } \\
\hline & & $(2)$ & $(3)$ & $(4)$ & $(5)$ \\
\hline Log Exports & $\begin{array}{c}1.297^{* * *} \\
(0.194)\end{array}$ & $\begin{array}{c}0.526^{* * * *} \\
(0.145)\end{array}$ & $\begin{array}{c}0.446^{* * *} \\
(0.135)\end{array}$ & $\begin{array}{c}0.370^{* * *} \\
(0.116)\end{array}$ & $\begin{array}{c}0.415^{* * *} \\
(0.139)\end{array}$ \\
\hline Log Distance & $\begin{array}{c}-0.677^{*} \\
(0.386)\end{array}$ & $\begin{array}{c}-1.608^{* * *} \\
(0.303)\end{array}$ & $\begin{array}{c}-1.523^{* * *} \\
(0.305)\end{array}$ & $\begin{array}{c}-1.546^{* * *} \\
(0.303)\end{array}$ & $\begin{array}{c}-1.894^{* * *} \\
(0.291)\end{array}$ \\
\hline Log Bilateral Exchange Rates & $\begin{array}{l}-0.0356 \\
(0.0753)\end{array}$ & $\begin{array}{c}-0.153^{* * *} \\
(0.0371)\end{array}$ & $\begin{array}{c}-0.155^{* * *} * \\
(0.0374)\end{array}$ & $\begin{array}{c}-0.124^{* * *} \\
(0.0394)\end{array}$ & $\begin{array}{c}-0.211^{* * *} \\
(0.0469)\end{array}$ \\
\hline Log GDP_country of origin (CoO) & $\begin{array}{c}-0.701^{* *} \\
(0.305)\end{array}$ & $\begin{array}{l}0.0122 \\
(0.250)\end{array}$ & & & $\begin{array}{l}-0.286 \\
(0.216)\end{array}$ \\
\hline Log GDP_country of destination & $\begin{array}{c}0.239 \\
(0.781)\end{array}$ & $\begin{array}{c}1.374^{* * *} \\
(0.447)\end{array}$ & $\begin{array}{c}1.366^{* * *} \\
(0.468)\end{array}$ & $\begin{array}{c}1.466^{* * *} \\
(0.454)\end{array}$ & $\begin{array}{c}1.442^{* * *} \\
(0.484)\end{array}$ \\
\hline Log Pop_country of origin & & $\begin{array}{c}0.745^{* * *} \\
(0.175)\end{array}$ & $\begin{array}{c}0.878^{* * *} \\
(0.161)\end{array}$ & $\begin{array}{c}0.623^{* * *} \\
(0.111)\end{array}$ & $\begin{array}{c}0.615^{* * *} \\
(0.196)\end{array}$ \\
\hline Log Pop_country of destination & $\begin{array}{l}-0.281 \\
(0.770)\end{array}$ & $\begin{array}{c}-0.795^{* *} \\
(0.345)\end{array}$ & $\begin{array}{c}-0.687^{*} \\
(0.359)\end{array}$ & $\begin{array}{c}-0.709^{* *} \\
(0.357)\end{array}$ & $\begin{array}{c}-0.708^{*} \\
(0.375)\end{array}$ \\
\hline Log Sum of exports over each $\mathrm{CoO}$ & & $\begin{array}{c}-0.534^{* * *} \\
(0.203)\end{array}$ & & & \\
\hline Log (GDP_country of origin-exports) & & & $\begin{array}{c}-0.399^{*} \\
(0.206)\end{array}$ & & \\
\hline Year & $\begin{array}{c}-0.0849^{*} \\
(0.0510)\end{array}$ & $\begin{array}{c}-0.0726^{* *} \\
(0.0292)\end{array}$ & $\begin{array}{c}-0.0819^{* * *} \\
(0.0304)\end{array}$ & $\begin{array}{c}-0.105^{* * *} \\
(0.0263)\end{array}$ & $\begin{array}{c}-0.0953^{* * *} \\
(0.0311)\end{array}$ \\
\hline Colony & $\begin{array}{c}0.589 \\
(0.605)\end{array}$ & $\begin{array}{l}0.423^{*} \\
(0.235)\end{array}$ & $\begin{array}{c}0.403^{*} \\
(0.238)\end{array}$ & $\begin{array}{c}0.556^{* *} \\
(0.237)\end{array}$ & $\begin{array}{c}0.605^{* *} \\
(0.241)\end{array}$ \\
\hline Constant & $\begin{array}{l}174.0^{*} \\
(98.93)\end{array}$ & $\begin{array}{c}149.2^{* * *} \\
(55.57)\end{array}$ & $\begin{array}{c}165.4^{* * *} \\
(57.90)\end{array}$ & $\begin{array}{c}209.9^{* * *} \\
(50.27)\end{array}$ & $\begin{array}{c}195.4^{* * *} \\
(58.82)\end{array}$ \\
\hline Observations & 590 & 590 & 590 & 590 & 500 \\
\hline R-squared & & 0.613 & 0.606 & 0.602 & 0.623 \\
\hline
\end{tabular}

Notes: We perform five different robustness checks. In the first one we run the regressions using a Poisson estimator. The population in the country of origin measures the exposure. In the second one we introduce as a regressor in the OLS the sum of all exports from a given Third Mediterranean Countriy $i$ to all European Union countries excluding country $j$, allowing for an indirect effect on migrations towards the European country $j$. In the third one we use $G D P$-exports of the country of origin instead of GDP. In the fourth one we don't control for GDP of the country of origin. In the fifth one we exclude Israel and Malta from the analysis. 


\section{A Data sources}

In our research we focus on those countries that took part to the Barcelona process with just a couple of exceptions: the Palestinian Authority and Libya. Although the former jointed the partnership, it has not been included in the analysis because the International Monetary Fund (IMF), that collects data on national bilateral trade in the "Direction of Trade Statistics" (DOTS), has no statistics on this country; as for the latter it is included in our research both for its dramatic economic and political importance in the region and because it belongs to the Union for the Mediterranean, which is the institutional evolution of the Euro-Mediterranean Partnership. Because of data limitations we use decennial data: 1970, 1980, 1990 and 2000. Data on national bilateral trade are expressed in US million dollars using the "Dyadic trade data" (the Inter-University Consortium for the Political and Social Research).

Data on migrations, available every 10 years, are from "Global Bilateral Migration Database" (The World Bank) and are expressed in thousands of migrants.

Data on the bilateral distance, contiguity and language come from the "Geodist" database (Centre d'études prospectives et d'informations inter-nationales) and are in kilometers.

Data on Purchasing Power Parity converted GDP and on population are taken from the "Penn World Table Version 7.0" (Center for International Comparisons of Production, Income and Prices at the University of Pennsylvania) and are expressed in million dollars.

Data on trade tariffs, measured as tax revenue on customs and import duties as percentage of GDP, are taken from the "Revenue Statistics - Comparative Series dataset" (OECD). Since the database has many missing data for most of EU countries we take data from the closest (in time) available year. In particular we use, 
for all the countries, data of 1997 instead of those of the year 2000 and, just for Ireland, data on the year 1971 instead of that of 1970. The empirical results are not that different when we do not make these substitutions, but we prefer to make the final analysis with a more complete dataset to make the results as much reliable as possible. Data on total imports are taken from "World Trade Flows: 1962-2000 NBER-United Nations Trade Data, 1962-2000" (Feenstra et al., 2005). Finally, data on the exchange rates are from the "Exchange rates crossrates, annual, 1970-2012" (UNCTAD). 


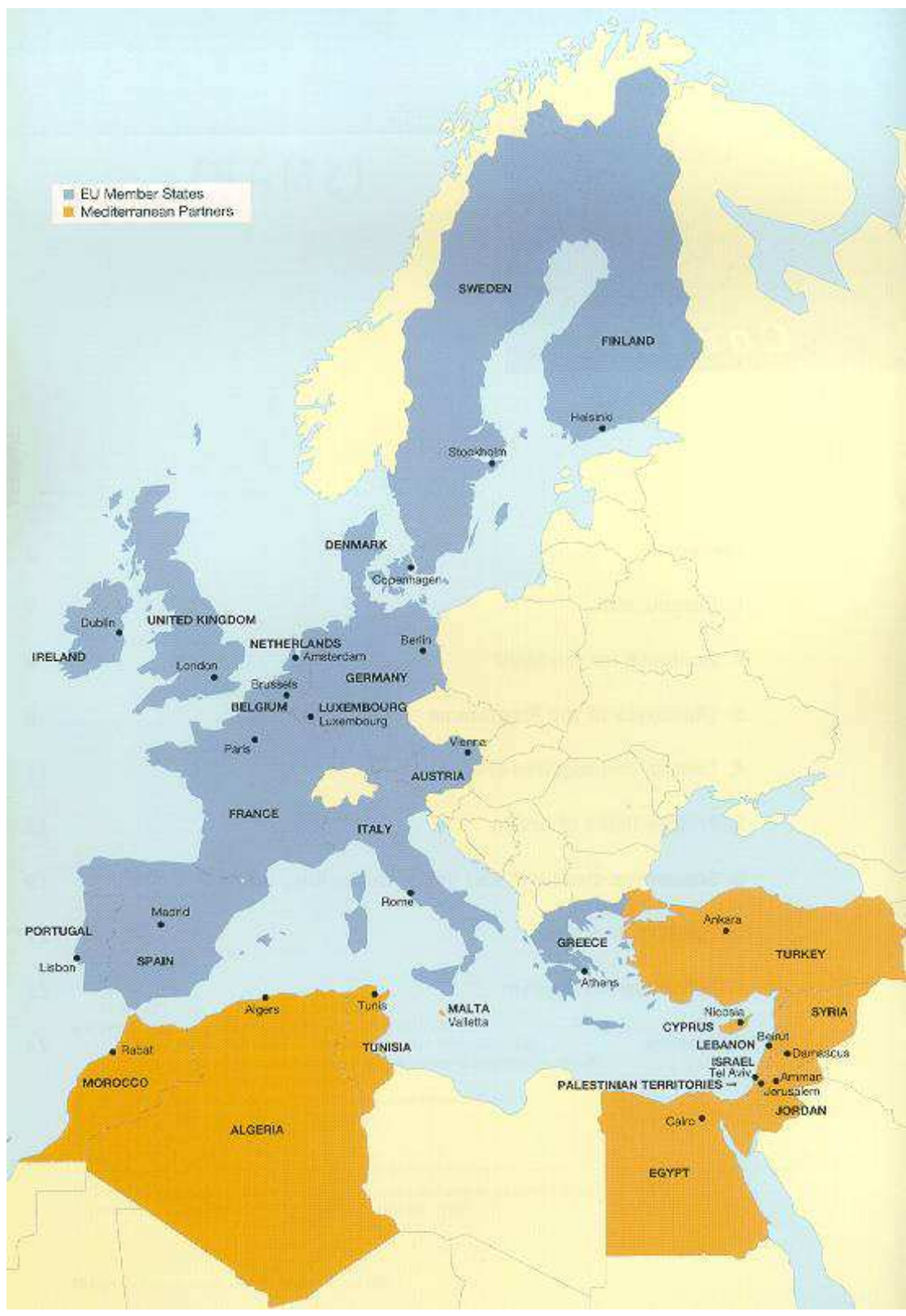

Figure 4: Countries of the Euro-Mediterranean Partnership.

Notes: We focus on these countries, but we include Libya and we exclude the Palestinian Authority. 


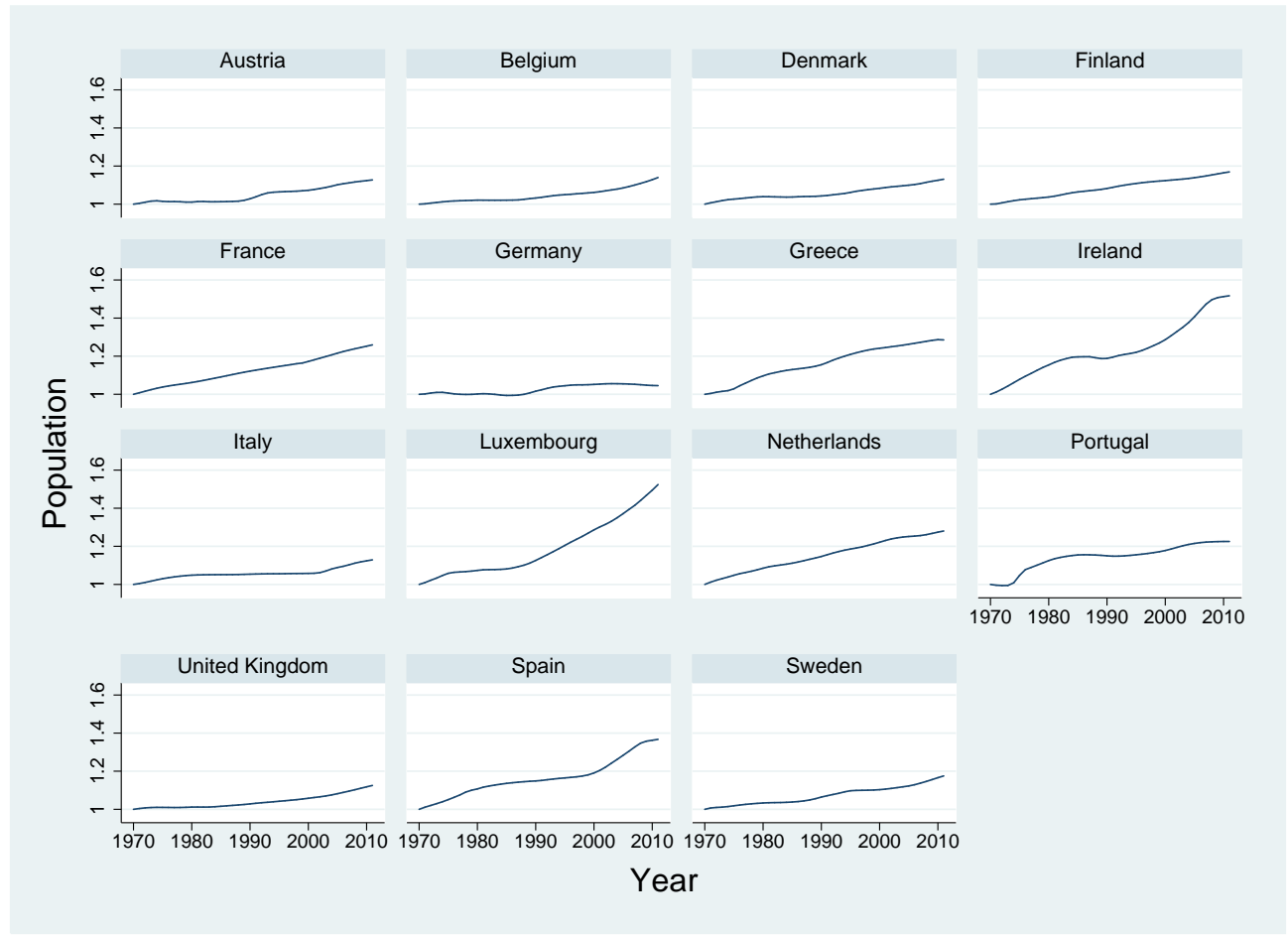

Figure 5: Population trends in the EU countries in 1970-2010.

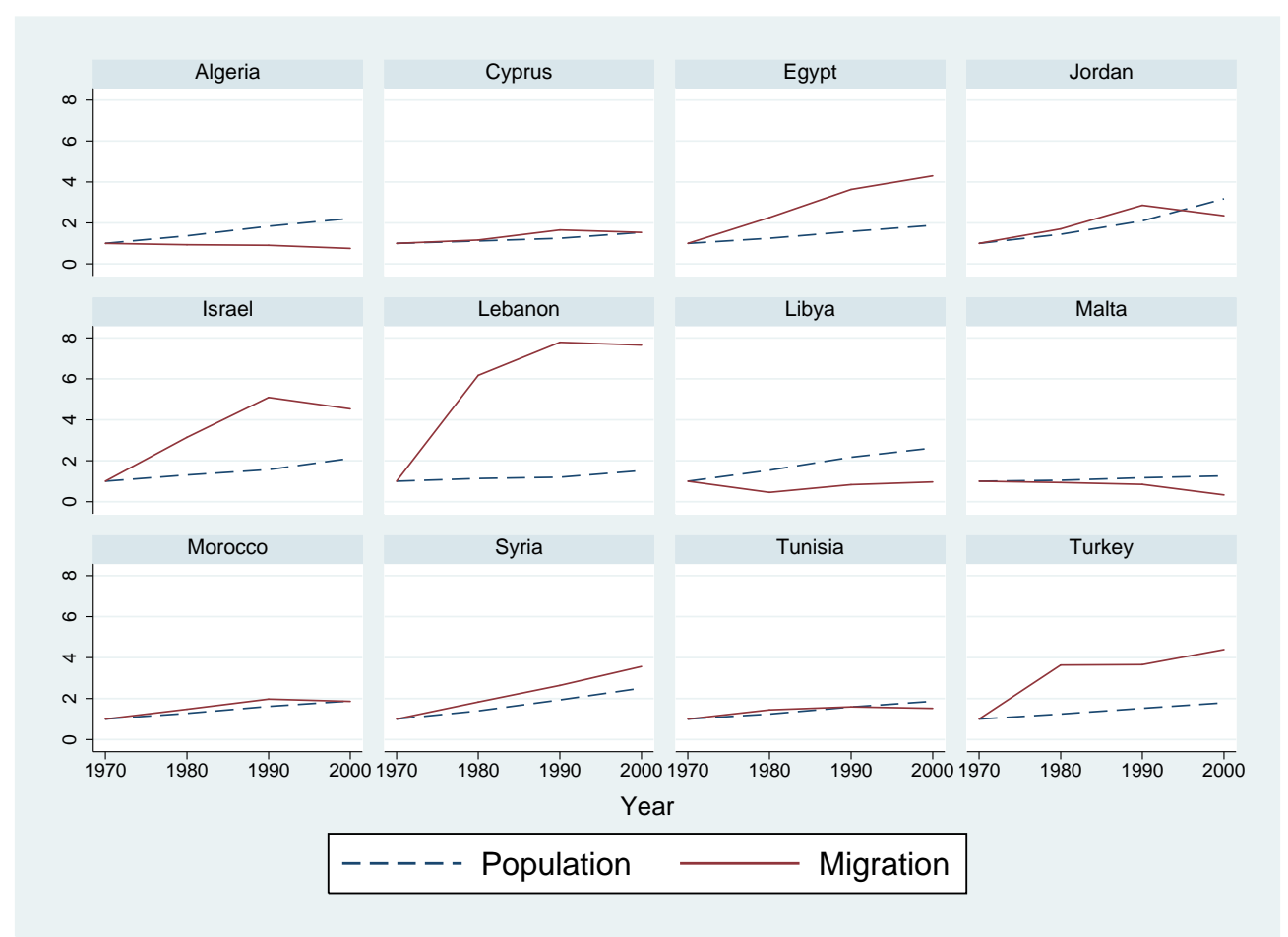

Figure 6: Population and migration trends in the Third Mediterranean countries in 1970-2000, normalized to be equal to 1 in 1970. 